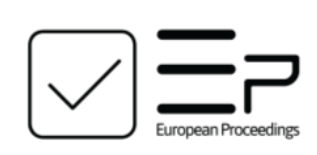

European Proceedings of

International Conference on Education \&

Educational Psychology

EPICEEPSY

www.europeanproceedings.com

e-ISSN: 2672-8141

DOI: $10.15405 /$ epiceepsy.21101.11

ICEEPSY 2021

$12^{\text {th }}$ International Conference on Education \& Educational Psychology

\title{
THE ATTITUDE OF KINDERGARTEN SPECIALISTS AND PARENTS TOWARDS INCLUSIVE EDUCATION IN PRESCHOOLS IN RUSSIA
}

\author{
Zhanna V. Antipova (a), Anna V. Boyarintseva (a), Vera V. Ryashina (a), \\ Alexandra A. Alekseeva (b)* \\ *Corresponding author \\ (a) TFSBSI «Institute of Study of Childhood, Family and Education of the Russian Academy of Education», \\ Moscow, Russia \\ (b) Independent Scholar. Profsoyznaya 107-33, 117279, Moscow, Russia. alekswiz@gmail.com
}

\begin{abstract}
Inclusion itself does not have a unique description yet, however the inclusive practices in education process are recognized as one of the most effective for children with SEN (Special Education Needs). However, kindergarten teachers may quite often experience difficulties in teaching children with SEN in inclusive preschool facilities. Authors suppose that this professional discomfort is happening due to lack of professional competence regarding inclusive education among teachers; as well as insufficient value of inclusion on their personal scale. 5166 respondents were offered a questionnaire of 21 questions with open and closed questions about the attitude towards inclusive education of children with SEN in preschools in Russia. The study showed the importance of adequate level and volume of professional support and training, designed specifically for the needs of kindergarten teachers. Some respondents turned out to be a valuable resourceful unit to organize trainings for others. Special training for kindergarten teachers to work with children with SEN inclusively should be considered as a process of forming their ability to solve specific professional problems.
\end{abstract}

2672-8141 C 2021 Published by European Publisher.

Keywords: Inclusion, kindergarten, inclusive education 


\section{Introduction}

The Federal Law of Education in the Russian Federation was adopted in 2012 (Ministry of Education and Science of the Russian Federation, 2012). Before then in the USSR and the Russian Federation preschoolers with disabilities received education in separate groups of a compensatory orientation. Children were to be sent to these groups by the Psychological-Medical and Pedagogical Commission (PMPC). Staff for these groups consisted of speech therapists, teachers for deaf-mute, typhlopedagogues, teachers for mentally disabled children, and tutors who knew the characteristics of children of a particular category (Prochukhaeva \& Medvedeva, 2004). However, since 2012 the number of inclusive groups has been rising and the question of professional requalification of the kindergarten teachers has been asked more and more often (Decree of the President of the Russian Federation, 2012, №761). There are a few researches on attitude, opinion and approach towards inclusive education in different regions of Russia. The size of the Russian Federation assumes that the answers received cannot be more different from each other than they already are. There are numbers of problems with inclusive groups' implementation (Budnikova \& Reznikova, 2017). Lack of information, books, specialists, mental unpreparedness are just a few. Nevertheless, the number of children with SEN is not going down; therefore, the refresher trainings are necessary. They should be different depending on the different views and approaches of teachers all over Russia.

\section{Problem Statement}

Inclusive education is recognized as one of the main conditions for realizing the rights of children with SEN to education (Grigorieva, 2009). However, kindergarten teachers may quite often experience difficulties in teaching children with SEN in inclusive groups of preschool facilities (Davidovich et al., 2020). Authors suppose that this professional discomfort is happening due to lack of professional competence regarding inclusive education among teachers; as well as insufficient value of inclusion on their personal scale (Akhmetova et al., 2013).

In April-May 2021 the authors conducted a study on the attitude of various target groups (kindergarten teachers, parents, administrative staff) towards inclusive education in preschool (Ministry of Education and Science of Russia, 2013) in 85 regions of Russian Federation. The research was undertaken in order to determine the technologies of working with teachers of inclusive groups.

\section{Research Questions}

The Research questions for this study were generated

3.1. To identify the attitude of teachers and parents of children towards inclusive education in preschools;

3.2. To determine the type of professional support (Borisova et al., 2016; Demicheva, 2012) needed for specialists working in the inclusive environment.

The analysis of the research results was based on 2 points: 
- If a respondent understands value of inclusion, as in understanding (or lack of understanding) of importance of inclusion for preschool education. The survey revealed the presence of the value of inclusion for $53.4 \%$ of the respondents, the absence of the value of inclusion for $46.6 \%$ of the respondents.

- The type of response of the respondent to the incorporation of inclusive work's formats in personal or professional activities. The authors used the Rosenzweig Theory of Frustration to determine the type of response. Frustration is a state of tension, disappointment, anxiety caused by dissatisfaction with needs; reasonably compellent (or subjectively so understood) difficulties, obstacles on the way to any important goal.

\section{Research Methods}

The respondents were offered a questionnaire containing 21 questions with open and closed questions about their attitude towards inclusive education of children with SEN in preschools in Russia. The questionnaire consisted of questions about the value of inclusion, the attitude towards people with various disabilities in modern society, the opportunities and difficulties of joint education in inclusive groups, potential scope of inclusive education in Russia, and also material, technical and methodological support for accompanying children with SEN (Alekhina et al., 2011; Tkacheva, 2014).

The sampling technique was purposeful where the selected respondents included kindergarten teachers and parents with preschool children.

5166 respondents took part in the survey. Employees of preschool educational institutions - 46.7\%, parents - 53.3\%. The surveyed employees of preschool educational institutions included: Kindergarten teachers $-72.2 \%$, Administration - 2.2\%, Methodologists - $0.9 \%$, Senior kindergarten teachers $-2.7 \%$, Junior kindergarten teachers $-3.2 \%$, Specialists of the service for accompanying children with SEN $-4.9 \%$, Music teachers - $4.3 \%$, P.E. instructors - $2.9 \%$, other employees - $7.7 \%$. The gender breakdown was $97.2 \%$ - female, $2.8 \%$ - male.

\section{Purpose of the Study}

To determine the level of professional discomfort or in contrast, readiness, of preschool teachers for the further implementation of inclusive practices in order to better understand the necessary measures for the implementation of inclusive education. The study was carried out on the basis of kindergartens registered as innovative platforms of Federal State Budgetary Scientific Institution under "Institute for Studying Childhood, Family and Upbringing of the Russian Academy of Education".

\section{Findings}

Three types of responses were identified:

1) The reaction is directed at oneself, with the acceptance of guilt or responsibility for correcting the situation that has arisen. The frustrating situation is not condemnable. The respondent accepts the frustrating situation as favorable for themselves. This reaction is typical for those respondents who already work in inclusive environment, accept its importance and necessity. They are ready to discuss the details and 
development of the inclusive process. Overall, this type of reaction is synchronous with a highly professional attitude. The group with such a response was termed as "Professionals". They made up $28.3 \%$ of the respondents.

2) This group's reaction reveals operating in an artificial environment. The external cause of frustration is condemned and the degree of the frustrating situation is emphasized. Sometimes the resolution of the problematic situation is required from another person. This kind of reaction is very private and vulnerable with a fixation on self-defense. It operates on a transfer of responsibility for inclusive practices to other teachers, strangers or the organization. The respondents with this reaction do not refuse to work in conditions of inclusion, but fixate on the lack of external assistance for such activities. Their behaviour is professionally inadequate and totals $36.5 \%$ of the subjects. This group was termed as "Imitators".

3) A frustrating situation is seen as something insignificant or inevitable, eminently preventable over time, with no blame for others or oneself. The respondents with this reaction perceive inclusion as something distant and unrelated to the real life of the kindergarten. It is an attitude towards inclusive practices as a distant future either as insignificant for oneself, or as inevitable, but not in a current kindergarten. This is an indefinite or fencing, indifferent professional response, which was shown by $35.2 \%$ of respondents. This group was termed as "Negativists".

For the following step, the authors combined the three types of responses and the presence (or absence) of the value of inclusion in their personal value-semantic field. Based on this analysis, six different professional groups emerged.

Group 1. The largest group turned out to be the "Imitators" with an existing personal value of inclusion at $31.8 \%$. They are characterized by the following sorts of answers: "we need to work within the inclusive field; however, I need special environment for myself, something important is missing, someone else should better do it rather than me". The respondents of this group show a lot of attention and even aggression towards external obstacles towards the realization of inclusive projects at the work place. They don't see it as their responsibility or take the opportunity to implement an inclusive approach in their kindergarten. They focus on objective and subjective obstacles in attaining inclusive goals, with reasons like the high number of kids in groups, lack of methodological materials or even personal issues (e.g. they have been taught differently, they are not good enough, etc).

Group 2. The second group comprises $25 \%$ of the "Professionals" with lack of value of inclusion. Their typical answers include "I am not familiar with inclusive methods yet, I have a lack of competences, I need to study more to know how to work with inclusive groups". The respondents value the importance of the job, understand self-responsibility to develop themselves professionally, ask a lot of questions, are ready to study and analyze their own experience and the experience of others

Group 3. There are quite a lot of respondents among the "Negativists" who value inclusion (18.3\%). They answered: "this activity is important, however somewhere else, not in my kindergarten, not for me, not now". These are fencing reactions; showing that there is no personal value for the respondent to work here and now in implementing inclusive educational practices, assuming these reactions depend on the level of education and professionalism.

Group 4. The "Negativists" with lack of inclusive value scored slightly lower at $16.9 \%$. They present the following answer options: "this is not currently in my work and most likely will not be, I do not 
see this, this activity should not be in my work at all". These are neutrally fencing reactions due to lack of knowledge among respondents while the study was conducted.

Group 5. There are very few respondents in the "Imitators" group with insufficient value of inclusion (4.8\%). They say "if I do not see it, it cannot exist". These are strictly negative reactions, up to aggression, that do not accept inclusion at all. The respondents would rather accuse and be aggressive towards their environment.

Group 6. The smallest percentage of the respondents with inclusion value (3.4\%) is in the "Professionals" group. Their answers follow the same pattern: "Yes, I understand and accept the essence of this activity, I want and can work with it, I try to do something here, but I need support, I have questions". It is a healthy orientation towards own skills, responsibility and profession overall.

It is important to provide the targeted scope and amount of professional support (Kapysheva, 2017) in working with different children in inclusive environment for each of the subgroups (1 to 6) identified in the study.

The authors offer a certain sequence of professional development, which includes the following five elements: reflection on professional experience and values of others; psychological support; informing; education; case study.

For Group 1, it is important to provide case studies with positive inclusive experiences, conduct reflection and special training. The respondents of this group need psychological support of their new professional position. They need to learn how to take responsibility and gain confidence in the new field. A transition to the Group 6 is possible with positive dynamics.

Group 2 has to be provided with information, special training, as well as professional support from specialists and personal work on mastering other people's experience. Positive dynamics can open a path to Group 6.

For Group 3, it is necessary to organize reflection and analysis of the conditions necessary and sufficient for this activity. Additional training is necessary to create valuable and helpful pool of information and familiarity with the positive experience (case study) of inclusive education.

Group 4 requires a reflection of professional and personal values, the acquisition of the value and meaning of inclusion, and basic training on the topic of inclusion.

Group 5 shows lack of knowledge and need to reflect on the professional values of inclusion. Also, professional psychological support is important here in order to help them take responsibility and gain selfconfidence in inclusive activities. Additional training, raising of awareness and positive case studies should be implemented.

Group 6 requires professional support from specialists through reflection on the personal experience of the respondents. This group can become a support and resourceful unit in the training of other colleagues in the preschool organization. Their positive experiences in inclusion can serve as an example for other educators and parents. 


\section{Conclusion}

Hence, the study showed the importance for each group to provide the adequate level and volume of professional support and training, designed specifically for its needs. Some respondents can become a resourceful unit to organize such training for others.

- In general, the study revealed the relevance of current work towards the development of professional consciousness and interest in the inclusive education for children with SEN during their preschool age.

- More than half of the respondents understands the value of inclusion showing up in their personal-semantic field (53.4\%).

- At only 3.4\%, there are very few specialists and parents who professionally understand and are ready to work within inclusive education. However, there are already sufficient numbers (25\%) of those who are ready to dive into inclusive perspectives.

- The creation of special conditions for inclusive work and shifting responsibility to other specialists and organizations lead the pack (32\%) in finding obstacles for the development of inclusive environment with $5 \%$ strongly reacting negatively to the possibility of the inclusive future.

- Exclusive courses need to be provided for each group of specialists, including specific professional support and training.

- A few specialists can become a resourceful unit in organizing the abovementioned courses.

Special training for kindergarten teachers to work with children with SEN inclusively should be considered as a process of enhancing their abilities to solve specific professional problems (Karpenkova et al., 2017), such as problems humanizing the joint education of children with and without SEN. The development of the personal, professional and value spheres of teachers need to be addressed to achieve this objective. (Eretnova, 2019).

\section{References}

Akhmetova, D. Z., Nigmanov, Z. G., Tchelnokova, T. A., \& Yusupova, G. V. (2013). Pedagogika $i$ psihologia inkluzivnogo obrazovania: utchebnoe posobie [Pedagogy and Psychology of Inclusive Education: a study guide]. Poznanie.

Alekhina, S. V., Alekseeva, M. N., \& Agafonova, E. L. (2011). Gotovnost pedagogov kaka osnovnoi factor uspeshnosti inkluzivnogo processa $\mathrm{v}$ obrazovanii [The readiness of teachers as the main factor in the success of the inclusive process in education]. Psychological Science and Education, 1, 83-92.

Borisova, N. A., Bukina, I. A., Buchilova, I. A., \& Lekhanova, O. L. (Ed.). (2016). Inkluzivnoe obrazovanie. Utchebnoe posoboe [Inclusive education. A study guide]. CHGU.

Budnikova, E. S., \& Reznikova, E. V. (2017). Realizatsia inkluzivnogo obrazovania v obrazovatelnoi organizatsii (Utchebnoe posobie dlya studentov visshih utchebnih zavedenii [Implementation of inclusive education in an educational organization (Textbook for students of higher educational institutions)]. Tsitsero.

Davidovich, L. R., Benilova, S. Y., Miklyaeva, N. V., \& Antipova, Z. V. (2020). Osnovi vospitania I obuchenia doshkolnikov s narusheniami v razvitii (Kompleksnaya profitaktika otklonenii v razvitii, integratsia v socium) [Fundamentals of education and training of preschoolers with developmental 
disabilities (Comprehensive prevention of developmental disabilities, integration into society)]. MPSU.

Decree of the President of the Russian Federation of June 1, 2012 N 761 (2012) "On the National Strategy of Action in the Interests of Children for 2012 - 2017" [In Russian]. http://base.garant.ru/70183566/\#ixzz6VfmMVxnY

Demicheva, O. G. (2012). Nespetsialnie problemi inkluzivnogo obrazovania [Non-specific problems of inclusive education]. Social pedagogics, 2, 54-58.

Eretnova, E. P. (2019). Inkluzivnoe obrazovanie v Rossii: ponyatie, zadachi, osobennosti [Inclusive education in Russia: meaning, questions, specifics]. Humanities research, 7. https://human.snauka.ru/2019/07/25997

Grigorieva G. F. (2009). Deti dolzhni uchitsya vmeste [Children must study together]. Qualitative education, 12, 70-71.

Kapysheva, N. D. (2017). Metodi inkluzivnogo obutchenia [Methods of inclusive teaching]. Science start, 4. https://science-start.ru/ru/article/view?id=418

Karpenkova, I. V., Samsonova, E. V., Alekhina, S. V., \& Kutepova, E. N. (2017). Tiutorskoe soprovozhdenie detei s ogranichennimi vozmozhnostyami zdorovia $\mathrm{v}$ usloviah inkluzivnogo obrazovania [Tutoring support for children with disabilities in inclusive education. Study guide]. MSPPU.

Ministry of Education and Science of the Russian Federation. (2012). Federal Law of Education of Russian Federation № 273-FZ of 29.12.2012 [In Russian]. https://fzrf.su/zakon/ob-obrazovanii-273-fz/

Ministry of Education of the Russian Federation (2013). Open register of Adapted Educational Programs of Education approved by the Ministry of Education of the Russian Federation [In Russian]. https://fgosreestr.ru/

Order of the Ministry of Education and Science of the Russian Federation of October 17, 2013 N 1155 (2013). On approval of the federal state educational standard for preschool education [In Russian]. https://rg.ru/2013/11/25/doshk-standart-dok.html

Prochukhaeva, M. M., \& Medvedeva, T. P. (2004). Opyt raboty integrativnogo detskogo sada [Experience in integrative kindergarten]. Tenerif.

Tkacheva, V. V. (2014). Semia rebenka s ogranichennimi vozmozhnostyami zdorovia: diagnostika I konsultirovanie [The family of a child with disabilities: diagnosis and counseling]. National Books' Center. 